\title{
Editorial
}

\section{Building a reputation; sharing an environment: Architecture and public diplomacy at the Venice Biennale of architecture, 2014}

\author{
Place Branding and Public Diplomacy (2015) 11, 1-4. doi:10.1057/pb.2015.1
}

One of the most enduring resources for place branding has always been architecture.

Prestigious buildings are the calling cards of their cities - think of Paris' Eiffel Tower, Sydney's Opera House or Moscow's St Basil's cathedral - and distinctive styles can embody entire regions as with the half timber of the English midlands, stave churches of Norway or whitewashed Dutch gables of South Africa's Western Cape. New buildings can serve as important points of attraction hence China has leveraged the Shanghai skyline and buildings associated with the 2010 Shanghai Expo, and the United Arab Emirates had makes capital of the astonishing built environment of Dubai. The process of design and professional practice of architecture adds another level of complexity. At their best architects can be reputational alchemists, empowering foreign clients with astonishing built environments. Frank Gehry is an asset to American soft power as Norman Foster is to the soft power of the United Kingdom.

Last year I used this space to consider the 2013 Venice Biennale of Art as a barometer of attempts to use the fine arts as a tool of place branding and public diplomacy, noting especially the strength of the Angolan pavilion which had been recognized with a golden lion. As a follow-up to that inquiry I returned to Venice in the autumn of 2014 to apply a similar approach to architecture and observe international contributions to the sister event the Biennale of Architecture. Architecture was always a strand within the Venice Biennale beginning with the design of the individual national pavilions, however in 1980 it split off into its own series of shows to run in the same network of venues in off years. Probably the most obvious beneficiary of an image boost from the 2014 biennale beside the ever compelling host city - was the Netherlands given that the 2014 show was curated by the distinguished Dutch architect Rem Koolhaas, creator of the China Central Television building and a string of other icons of contemporary design. Koolhaas made his presence felt declaring an overall theme for the biennale of

'Fundamentals' and on top of this requesting national pavilions to contribute to a shared 'research theme' for the first time. His choice of theme - 'Absorbing Modernity, 19142014' - provided a challenge for national architectural communities to consider their own achievements and no less significantly some of their follies. The turn towards coherence did not deter participation. A record 65 nations came to Venice for this biennale including such surprising holdouts as New Zealand. The national pavilions were joined by two other elements developed by Koolhaas: an exhibit around the relationship between architecture and art in Italy called MondoItalia and an exhibit in 
the central pavilion exploring the fundamental components of architecture. MondoItalia integrated static exhibits and installations with spaces for music, dance and film. Installations included a church confession box fitted with a television playing the speeches of Silvio Berlusconi on a loop. The Elements of Architecture exhibit largely created with the Harvard School of Design - explored the historical evolution of the basic architectural components: doors, windows, roofs and so forth - as modernity took shape. A particularly memorable section dealt with the development of the corridor from its origin as a person with the role of messenger - to its zenith as the characteristic feature of modernist bureaucracy as memorialized in the phrase 'corridors of power.' But what of the exhibiting nations?

As far as the prize jury was concerned the best pavilion was that of the Republic of Korea. This is perhaps not surprising given the tremendous attention which South Korea has given to its image in recent years. What was surprising was the approach. In contrast to much recent South Korean 'nation branding' the pavilion 'Crow's Eye View: The Korean Peninsula' met the issue of the North/South division head on and used the theme of modernity to create a record of the shared experience across the peninsula, pointing both commonalities and contrasts in the experience of the built environment either side of the 38th parallel. Historic propaganda posters urging each side in diametrically opposite directions were much in evidence, but the underlying mood was one of optimism and a mutual compatibility founded on the shared architectural heritage, suggesting that reunification was a matter of time.

The runner up for the golden lion was a more intimate offering but no less moving in approach. The Chilean pavilion confronted the connection between its modernism and the country's tragic history through the story of a single Soviet-made concrete window panel imported around 1970. The block was personally dedicated by President Salvador Allende and therefore selected for symbolic repurposing by the regime of General Augusto Pinocet once Allende was overthrown. It became a frame for a religious shrine for the duration of that regime's rule. The original panel- dubbed the monolith - was installed in the center of the pavilion as a single immense, austere relic, contrasting with the warmth and clutter of the typical Chilean living room through which visitor's entered. The result was thought provoking and continues Chile's run of interesting exhibits exemplified by its wonderful contribution to the Shanghai Expo back in 2010.

The judges also made special mention of France, Canada (an exhibit on architecture in the arctic) and Russia. As observers of international exhibitions are well-aware Russia has made a particular effort in recent years to make a splash. This care is a reflection of the same spirit of national projection that is propelled the Sochi Olympics, Yekaterinburg's unsuccessful bid for the 2020 Expo and the rapid expansion and upgrading of the country's international broadcasting. The Russian pavilion here was a charmer with small installations displaying some characteristic elements of Russian style in the past and a fairly unflinching exploration of the excesses of Soviet modernism, including images of Soviet inspired constructions in the United Kingdom and elsewhere.

If the element of self-criticism was unexpected in the Russian pavilion it was a fairly predictable part of in the British offering: Britain has never been shy of incorporating self-criticism or deprecation into its cultural diplomacy and engagingly themed its pavilion around the problems of modernist architecture in the country. The exhibit was called 'Clockwork Jerusalem', a title which united William Blake's poem of hope of what Britain could become with the bleak response of Anthony Burgess novel (and its film adaptation) A Clockwork Orange to the reality of the 1960s. Intriguing for scholars of propaganda were a couple of posters crafted during World War Two to sell a modernist urban vision of the United Kingdom which were censored by Winston Churchill in favor of pastoral scenes of England's rolling hills. The exhibit did not flinch from showing the excesses of British post-war urban architecture but demonstrated that problems were no barrier to engaging an audience.

Some of the star exhibits were easy to predict. Both Brazil and Mexico leant heavily of 
architectural excellence in the 1950s and 1960s and materials from that period remain impressive. The Brazilian show grouped images of the country's architecture by type, showing the evolution of home, work, diplomatic and other kinds of structures from colonial times to the present. Even a picture of Oscar Niemeyer's flying-saucer like Museum of Modern Art in Niteroi has the power to command attention. Mexico's exhibit looked at the tension between modernity and the older ideas of Mexican identity taking a quotation from Octavio Paz: 'condemned to be Modern' as its title. The pavilion explored the ways in which Mexico's often violent encounter with modernity had paradoxically propelled a quest back into its pre-Columbian past.

Some pavilions were explicitly political. Modernity had troubling implications for South Africa and that country's powerful pavilion drew out the modernist elements within the ideology of apartheid, but perhaps the most astute comment of the conjunction of architecture and politics was the brilliant installation at the Austrian pavilion called 'Plenum, places of power.' The core of this exhibit was a collection of white painted models of every parliament building in the world made to the same 1-500 scale and mounted on the wall. Some were tiny squares, some familiar icons of governance, others alien, some literally looking like spacecraft from other worlds. Their reduction and repetition rendered them some how silly and underlined their fundamental nature at the same time. The pavilion included a garden into which extracts of live European Union debates were piped over small loud speakers.

One of the pleasures of a festival like the biennale is the opportunity for unexpected contenders to shine by dint of ingenuity rather than budget. Unexpected stars in the arsenale space included a number of Balkan countries. Slovenia developed a display around the ethnically Slovene futurist Herman Potočnik Noordung whose 1928 essay 'The Problem of Space Travel' was one of the first to develop at length the necessary shape of architecture beyond earth's gravity. He imagined a giant wheel-shaped space station with stairways inside spiral radial passages and airlocks to allow access the outside void. The clever thing was the exhibit's use of an unexpectedly angled floor to induce a momentary sensation of weightlessness as the visitor stepped in. Hardly less impressive was the contribution from Kosovo (named 'Imposed Modernity') which repurposed several hundred of the country's traditional low three legged, semicircular-seated stools fixed seat-edge to seat edge on their side to build a cylindrical tower. It was a neat metaphor for the way in which the resources of the past are used to build the present. Albania also struck a chord with an installation called 'Potential Monuments of an Unrealized Future' built around a series of prints and a film installation. The film by Adrian Paci showed Chinese workers on a factory ship carving a piece of solid marble into a classical pillar during the voyage from the quarry to its European destination. It lay on the quay outside the exhibit. The prints by Edi Hila showed columns of color with houses forming as in a dream at their very top. The whole thing was designed by Beyond Entropy, the design collective behind the Angola's success in 2013. Their work plainly deserves future attention.

Of the regions making a particular effort to shine at the biennale, the Middle East stood out. Both Morocco and Bahrain took the stereotype bull by the horns with pavilion titles that punned on the word fundamentalism ('Fundamental(ism)s' and 'Fundamentalism and other modernisms' respectively). United Arab Emirates was especially impressive with 'lest we forget, structures of memory in the United Arab Emirates' which presented an archive of the astonishing evolution of modern building in the Gulf states over the last half-century. Collectively the contributions opened a fresh window on the regions desire to move forward without losing touch with one's origins and represented a worthy exercise in public diplomacy.

But what of the perennial antagonists for international admiration: the United States and China? The US contribution was a fascinating living exhibit called Office US which served as a walk-through catalog of every major building by an American architect build outside the country since 1914 - embassies were strongly represented 
though the Barbie doll flagship store in Shanghai was also present - while the middle of the pavilion was given over to a number of young American architects actually working as part of a temporary office for the duration of the biennale. Given the excellent standard of recent Chinese exhibits the China's contribution was surprisingly underwhelming - a structure of tunnels and arches build from sticks called 'Mountains beyond Mountains' with a parallel exhibit of photographs of rather dull buildings from the eighties. An installation built from flooring material made out of pressed garbage held some interest more especially when the excellent pavilion docent showed how one could still make out shreds of text within its surface. The problem for China was made clear in a general orientation display at the entrance to the arsenale exhibition space. A poster gave comparisons of the number of trained architects per capita around the world. Italy led the field with an astonishing 300 architects for every citizen. Most countries sat in a bulge around 1500-2000 or so, but China stood out as architectpoor, with one architect for each 35750

inhabitants. To be fair we were not told the figure for China's rival BRICS but the point was powerfully made. It was a gauntlet thrown down for the future: a challenge which we may assume given that country's vigorous response on so many reputational fronts - will be taken up in due course.

Reflecting on the 2014 Venice biennale of architecture I am struck not so much by the value for the national exhibitors of participating in these kinds of cultural diplomacy events as the power inherent in the subject matter celebrated here. Architecture retains a unique ability to move - as befits the art form characterized by Goethe's as petrified music - and a special capacity to serve as a site of international engagement. Practitioners cross frontiers, mix styles and materials, interact with existing environments and cooperate with local colleagues to create a hybrid form of culture which ultimately defies attempts to contain or harness it for the benefit of any one state or political agenda. It is testament to the vision of Rem Koolhaas that despite the nationally stovepiped nature of the biennale so much of the commonality could shine through.

Nicholas J. Cull University of Southern California, Los Angeles, USA. E-mail: cull@usc.edu 